\title{
Knowledge Capabilities in Supply Chain Networks: A Taxonomy
}

\author{
Robert Ogulin \\ University of Sunshine Coast, Australia \\ rogulin@usc.edu.au \\ Gustavo Guzman \\ Griffith University, Australia \\ g.guzman@griffith.edu.au \\ Subasinghage Maduka Nuwangi \\ Auckland University of Technology, New Zealand \\ maduka.subasinghage@aut.ac.nz
}

\section{Please use the following citation:}

Ogulin, R., Guzman, G., \& Nuwangi, S. M. (2020). Knowledge capabilities in supply chain networks: a taxonomy. Journal of Knowledge Management. DOI 10.1108/JKM-06-2019-0266. 


\title{
Knowledge Capabilities in Supply Chain Networks: A Taxonomy
}

\begin{abstract}
Purpose - This paper develops a conceptual taxonomy for building requisite knowledge capabilities for different supply chain network (SCN) types. Specifically, it examines knowledge capabilities required for three types of SCNs: efficient, collaborative and agile SCNs.

Design/methodology/approach - This paper integrates two bodies of thought (i.e. knowledge management and organisational learning) and applies them to SCNs. We use an abductive research process to develop this conceptual taxonomy.

Findings - The conceptual taxonomy details three archetypical knowledge capabilitiesexploitation, exploration and ambidextrous. Those knowledge capabilities are required for efficient, collaborative and agile SCNs, respectively.

Research limitations/implications - This paper is conceptual and theory-based. The next stages of the research seek to further strengthen the explanatory value of the taxonomy through empirical validation.

Practical implications - The taxonomy developed in this paper provides a valuable and pragmatic tool for managerial decision-making in the context of SCNs. Specifically, it provides a roadmap for practitioners since the study develops an understanding of the relationship between knowledge capabilities and types of SCNs.
\end{abstract}

Originality/value - This is one of the earliest studies that attempts to unearth requisite knowledge capabilities for different types of SCNs.

Keywords - Supply chain networks, knowledge capabilities, taxonomy, network types, exploitation, exploration

Paper type - Conceptual paper 


\section{Introduction}

Knowledge and learning have emerged as important factors to maintain competitiveness in supply chain networks $(\mathrm{SCNs})^{1}$, which are increasingly complex, global and fast-paced (Hult et al., 2007; Christopher, 2012; Blome et al., 2014; Attia and Essam Eldin, 2018). SCNs are driven by various market needs, have different resource endowments, and are subject to a variety of external influences from customer and suppliers. Thus, SCN partners need to develop knowledge capabilities that are congruent with the requirements of customers, suppliers and market participants (Wycisk et al., 2008; Rangachari, 2009; Potter et al., 2015).

Past studies of KM capabilities have elaborated on infrastructure capabilities (e.g. technological and structural); process capabilities (e.g. acquisition and application of knowledge) (Gold et al., 2001; Wong and Wong, 2011; Singh and Dalcher, 2011; Pandey and Dutta, 2013); relationships between dynamic capabilities and performance in network organizations (Pereira et al., 2019); and, the role of process capabilities and organizational learning on the firm's performance (Freeze and Kulkarni, 2007; Wu and Chen, 2014). Knowledge capability typologies (Nielsen, 2006; Denford, 2013) have developed KM capability frameworks and suggested common dimensions (e.g. internal versus external sourcing of knowledge; exploitation versus exploration of knowledge; and creating and assimilating knowledge).

Those studies, while advancing the understanding of knowledge capabilities, have not detailed the required knowledge capabilities for diverse types of SCNs (Van Wijk et al., 2011). We posit that knowledge capabilities in SCNs need to be deliberately built within interconnected relationships to provide opportunities for learning (Cambra-Fierro et al., 2011). There are limited insights about what specific knowledge capabilities diverse types of SCNs need to develop and, how they can develop those capabilities.

Acknowledging that diverse types of SCNs demand different knowledge capabilities as well as that diverse knowledge capabilities require different forms of knowledge and learning (Zahra and George, 2002; McIver et al., 2013), the aim of this study is to develop a conceptual framework that details specific knowledge capabilities for diverse types of SCNs. Using a knowledge capabilities perspective and building on the notions of absorptive capacities (Cohen and Levinthal, 1990) and dynamic capabilities (Teece et al., 2000, Teece,

\footnotetext{
${ }^{1} \mathrm{SCNs}$ are networks of connected and interdependent organisations mutually and co-operatively working together to control, manage and improve the flow of materials from suppliers to end users (Christopher, 2016).
} 
2007), this article details what knowledge capabilities are required by diverse types of SCNs and, how those knowledge capabilities can be developed. By aligning two bodies of thought - KM and organizational learning — and apply them to SCN literature, the authors develop a conceptual taxonomy connects required knowledge capabilities to three archetypical SCN types (see figure 1):

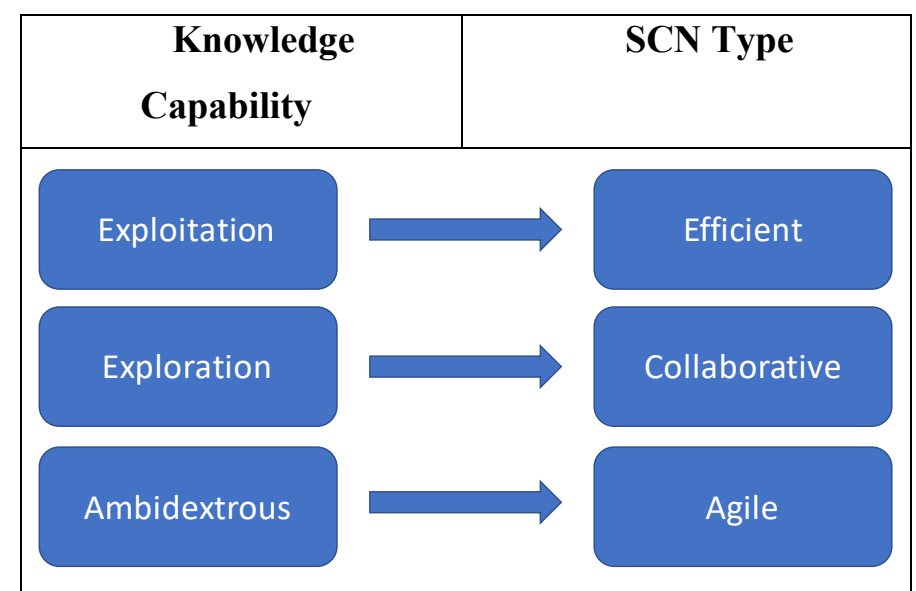

Figure 1. Knowledge Capability required by different types of SCNs

The authors posit that exploitation knowledge capabilities support efficient SCNs, exploration knowledge capabilities sustain collaborative SCNs and ambidextrous knowledge capabilities foster agile SCNs.

In this study, the concept of knowledge capabilities refers to a specific combination of the firms' tangible and intangible knowledge assets, competencies and activities that support competitive advantage. Building on March (1991); Stettner and Lavie (2014) and Bolisani and Bratianu (2017), we distinguished three types of knowledge capabilities: (i) exploitation, that enable the (re)use of existing knowledge; (ii) exploration, that focus on search/assimilation of new knowledge and; (iii) ambidextrous, that facilitate adaptation of its knowledge base to shifting market demands (that is, it's a dynamic application of exploitation and exploration capabilities).

Drawing from Choi et al., (2001) and Christopher, (2012), we categorised SCNs into three types: (i) efficient $\mathrm{SCN}$, which focusses on minimising the costs through streamlining operational activities; (ii) collaborative $\mathrm{SCN}$, which aims to develop competitive advantage through flexibility and the integration of network-wide operational activities; and (iii) agile $\mathrm{SCN}$, which aims to achieve, simultaneously, efficiency and flexibility while striving for continuous self-renewal and value-creation for all stakeholders.

Additionally, knowledge is closely connected to learning since knowledge is the outcome of learning processes (Argote and Miron-Spektor, 2011). Learning involves 
creating options, experimenting and developing alternative solutions to cope with different degrees of complexity in search for novel solutions (Christopher and Peck, 2004; Weick and Sutcliffe, 2007). It is a social practice that involves the reconstitution of cognition and identities (Antonacopoulou and Chiva, 2007). In this framework, we explore the behavioural and cognitive dimensions in which knowledge and learning play out in the context of different SCNs (Capó-Vicedo et al., 2011; Antonacopoulou and Chiva, 2007) and, elaborate research propositions. Table 1 synthetises research questions and advances research propositions. Detailed explanations on the development of research questions and the propositions are provided in the following sections.

Table 1. Research questions and propositions

\begin{tabular}{|c|c|}
\hline $\begin{array}{l}\text { RQ1: what knowledge capabilities } \\
\text { are required by diverse types of SCNs? }\end{array}$ & $\begin{array}{l}\text { RQ2: how to develop the knowledge capabilities } \\
\text { required by diverse types of SCNs? }\end{array}$ \\
\hline \multirow[t]{3}{*}{$\begin{array}{l}\text { Exploitation knowledge capability is } \\
\text { the basis of efficient SCNs }\end{array}$} & $\begin{array}{l}\text { Proposition 1. Codified knowledge is the basis for } \\
\text { developing exploitation knowledge capability in } \\
\text { efficient SCNs. }\end{array}$ \\
\hline & $\begin{array}{l}\text { Proposition 2. Single-loop learning sustains the } \\
\text { exploitation of knowledge in efficient SCNs. }\end{array}$ \\
\hline & $\begin{array}{l}\text { Proposition 3. Feedback learning processes } \\
\text { support exploitation knowledge capability in efficient } \\
\text { SCNs. }\end{array}$ \\
\hline \multirow[t]{3}{*}{$\begin{array}{l}\text { Exploration knowledge capability is } \\
\text { the basis of collaborative SCNs }\end{array}$} & $\begin{array}{l}\text { Proposition } 4 \text {. Relational and somatic tacit } \\
\text { knowledge are the basis for knowledge exploration } \\
\text { capability in collaborative SCNs. }\end{array}$ \\
\hline & $\begin{array}{l}\text { Proposition 5. Double-loop learning dominates } \\
\text { knowledge exploration capabilities in collaborative } \\
\text { SCNs. }\end{array}$ \\
\hline & $\begin{array}{l}\text { Proposition 6. Feed-forward learning processes } \\
\text { support knowledge exploration capabilities in } \\
\text { collaborative SCNs. }\end{array}$ \\
\hline $\begin{array}{l}\text { Ambidextrous knowledge capability } \\
\text { is the basis of agile SCNs }\end{array}$ & $\begin{array}{l}\text { Proposition } 7 . \text { Comprehensive tacit } \\
\text { knowledge (i.e. relational, somatic and collective tacit } \\
\text { knowledge) and codified knowledge support } \\
\text { ambidextrous knowledge capabilities in agile SCNs. }\end{array}$ \\
\hline
\end{tabular}




\begin{tabular}{|l|l|}
\hline & $\begin{array}{c}\text { Proposition 8. Deutero-learning supports the } \\
\text { ambidextrous knowledge capabilities in agile SCNs. }\end{array}$ \\
\cline { 2 - 3 } & $\begin{array}{l}\text { Proposition 9. Both feedback and feed-forward } \\
\text { learning processes support ambidextrous knowledge } \\
\text { capabilities in agile SCNs. }\end{array}$ \\
\hline
\end{tabular}

This paper is structured as follows. Section 2 presents the methodological considerations of the research. In section 3, the conceptual taxonomy and propositions are detailed. Finally, section 4, discusses the implications for future research, relevant outcomes for management practice and the limitations of the study.

\section{Methodological Considerations}

This article is conceptual and follows an abductive research process to develop a framework that shows requisite knowledge capabilities for different SCN types.

Conceptual frameworks, or taxonomies, provide an explanatory structure to categorise phenomena in a coherent and meaningful way, as well as to describe the interrelationships of the components to explain how/why they occur (Whetten, 1989; Corley and Goia, 2011). Taxonomies are a unique form of theory building (Doty and Glick, 1994). As opposed to empirical studies that aim to test hypotheses and assess research for its contributions to existing theories (Yadav, 2010), conceptual taxonomies lead to new concepts that open avenues for understanding a phenomenon. Conceptual frameworks help develop new models, which ultimately contribute to theories that explain the nature of the domain of inquiry (Shapira, 2011). Hence, a key strength of conceptual taxonomies is that their creative scope remains freed by data-related limitations (Yadav, 2010; MacInnis, 2011). Noteworthy, while taxonomies identify ideal types of SCNs (Doty and Glick, 1994), actual organisations may belong to one or more ideal types of the taxonomy. Similarly, SCNs may consist of multiple knowledge orientations, learning modes and learning processes.

Rather than using a gap-spotting technique (Alvesson and Sandberg, 2013) based on a systematic literature review for the construction of the proposed conceptual taxonomy, we followed an abductive research process (Timmermans and Tavory, 2012). An abductive approach is suited to uncover new insights about the relationships between SCNs and diverse forms of knowledge and learning by extending and combining existing theories in novel ways (e.g. Kovács and Spens, 2005). The process of abductive research started with the empirical 
observation of different forms of SCNs, on the one hand, and the acknowledgement of a variety of forms of knowledge and learning processes on the other. Next, the authors looked for characteristics of particular SCNs. Thereafter, specific forms of knowledge and learning processes were matched to these archetypical forms of SCNs. This involved iterative forwards and backwards processes attempting to align, match and combine SCN types to knowledge and learning forms. This process was supported by the combination of the authors' research and field experiences-instincts, socially cultivated ways of seeing the world, biographies and intentions (Timmermans and Tavory, 2012). One of the authors is an expert in SCNs, specialising in agile forms of networks, another author's expertise resides in the field of KM and learning, while another author's specialisation is in information systems in inter-organisational operations.

\section{A Taxonomy for Knowledge Capabilities in Supply Chain Networks}

Acknowledging that knowledge attributes and organisational learning are considered fundamental elements that underpin knowledge capabilities (Nelsen, 2006; Freeze and Kulkarni, 2007; Vera, Crossan and Apaydin, 2011; Van Wijk et al., 2011), we consider that knowledge capability is composed by knowledge attributes (March, 1991; Tsoukas, 2011; Van Wijk et al., 2011), prevailing learning modes (Argyris and Schon, 1978) and learning processes (Crossan et al., 2011). We consider that knowledge capabilities (that is, knowledge assets, competencies and activities) can acquire a range of knowledge attributes and can be learned through diverse learning modes and learning processes. This means, that different combinations of knowledge attributes, learning modes and learning processes, suit the market demands of three archetypical SCNs: efficient, collaborative and agile SCNs as shown in Table 2. This framework explains how knowledge attributes shift with learning processes with which they are associated (Turner and Makhija, 2006) and how they align with different SCN types.

Table 2. Requisite knowledge capabilities and SCN types

\begin{tabular}{|c|l|l|l|}
\hline $\begin{array}{c}\text { Knowledge } \\
\text { Capability }\end{array}$ & Exploitation & Exploration & Ambidextrous \\
\hline $\begin{array}{c}\text { Knowledge } \\
\text { attributes }\end{array}$ & Codified & $\begin{array}{l}\text { Relational tacit } \\
\text { Somatic tacit }\end{array}$ & $\begin{array}{l}\text { Codified } \\
\text { Relational tacit } \\
\text { Somatic tacit }\end{array}$ \\
\hline
\end{tabular}




\begin{tabular}{|l|l|l|l|}
\hline & & & Collective tacit \\
\hline Learning mode & Single-loop & Double-loop & Deutero \\
\hline Learning process & Feedback & Feed-forward & $\begin{array}{l}\text { Feedback and } \\
\text { Feed-forward }\end{array}$ \\
\hline SCN Type & Efficient & Collaborative & Agile \\
\hline
\end{tabular}


The concept of knowledge capabilities refers to a specific combination of the firms' tangible and intangible knowledge assets, competencies and activities that support the generation, use, exchange and sharing of knowledge (Sappington and Bedford, 2017; Marr, et al., 2004; Yang and Chen, 2007). Tangible knowledge assets include data, information, software and organisational procedures stored in documents and information systems. According to the intellectual capital literature (Sappington and Bedford, 2017; Choo and Bontis, 2002), intangible knowledge assets include knowledge, information, skills, experience and competences that are in people's minds and bodies, which enable relationships with customers, supplier and partners. Knowledge capabilities facilitate the development of adaptive network configurations which are aligned with customer needs and supports the creation of value networks that can lead to competitive advantage (Cerchione and Esposito, 2016; Durst and Evangelista, 2018). Knowledge capabilities encompass knowledge assets, competences and activities for monitoring and sensing the external environment (searching new knowledge or knowledge exploration capability); assimilating, adapting and utilising existing knowledge (knowledge exploitation capability) (Zahra and George, 2002; March, 1991; Saenz et al., 2014) and; for ongoing knowledge adaptation to changing market conditions through a flexible combination of resources and skills (Ambidextrous knowledge capability) (Teece et al., 2000, Teece, 2007).

This study considers the four types of knowledge: codified, relational-tacit, somatic-tacit and collective-tacit knowledge. They cover tangible and intangible knowledge assets, competencies and activities with a range of knowledge attributes.

Codified knowledge is "regarded as an entity/commodity that people possess, but which can exist independently of people. Such knowledge can exist in the form of documents, diagrams, computer systems or be embedded in physical artefacts such as machinery or tools" (Hislop, 2005, p. 17). In supply chains, codified knowledge is usually transmitted through technologies such as Electronic Data Interchange, ERP systems and collaborative websites (Lin et al., 2002). Tacit knowledge is subjective as well as related to human competences and experiences in a particular context. Accordingly, it exists in human brains (Wu, 2008) and can be acquired through learning-by-doing and experimentation (Bhosale and Kant, 2016, p. 7377)

The taxonomy presented in this paper considers three types of tacit knowledge suggested by Collins (2010). First, relational tacit knowledge describes knowledge that cannot be explicated because of the complex social and relational attributes embedded within it. That is, it 
is tacit because some of its attributes are subjected to interpersonal interaction or attention. For example, relational tacit knowledge is the knowhow that SCN partners develop over time about the strength and reliability of the cooperation in the network (Van Wijk et al., 2011). Somatic tacit knowledge is related to the capabilities and limitations of the human body (Collins, 2010). It is tacit due to our body's inherent physical limitations and abilities. It can only be learned through practice. For example, humans can only demonstrate some interpersonal abilities by doing certain tasks but, are unable to fully articulate and explain how they perm this task. Third, collective tacit knowledge refers to knowledge that is located within a social group and only members can access it. Collective tacit knowledge is knowledge that is ingrained in society and depends largely on how society works (Sohrabi and Naghavi, 2014, p. 366). For example, improvisation skills can only be acquired through social embedding in a group, since social sensibility is required to reflect on the adequacy of the improvised actions in the context of multiple individuals.

Learning modes focus on the cognitive aspects of the learning process. Argyris and Schön (1978) identify three learning modes. The first, single-loop learning, involves applying standard operating procedures (rules) and concepts to monitor and carry out activities. It works well in stable and predictable contexts. The second, double-loop learning (meta-learning), includes updating the actual governing variables, norms and values embedded in the standard operating procedures applied to cope with novel situations. The third, deutero-learning, refers to inquiring into processes of learning at the individual and group level. It involves awareness reflexivity and a shift in the whole learning process (Tosey et al., 2012, p. 295). In other words, it is about judging when and how to carry out single and double-loop learning. This form of learning is only partially cognitive and mostly unconscious (Visser, 2007).

Learning processes focus on the social and psychological aspects of learning between individuals and groups. Crossan et al. (2011) propose four learning processes that link three levels of analysis: intuiting and interpreting unfold at the individual level, integrating occurs at the group level, and institutionalising arises at the organisational level. Organisational learning involves assimilating both new knowledge (exploration) and using existing knowledge (exploitation). Notably, feed-forward processes (from individuals' intuiting and interpretation processes, through group and integration, to institutionalising at the organisational level) support exploration activities. Conversely, feedback processes (from the organisational level to the group and individual levels) support knowledge exploitation activities (Bontis et al., 2002). 
Considering the definitions of the key elements of knowledge capabilities (knowledge attributes, learning mode and learning processes), Table 3 further details the features of exploitation, exploration and ambidextrous knowledge capabilities. Similarly, Table 4 summarises key features of three archetypical SCNs.

$<$ Insert Table 3 'Types of Knowledge Capabilities’>

$<$ Insert Table 4 'Types of Supply Chain Networks'>

In the following section we review in detail the dimensions of our taxonomy. We provide relevant literature and research and develop propositions for discourse and further research.

\subsection{Knowledge capabilities required by efficient supply chain networks}

Efficient SCNs are driven by the constant search for efficiency gains through the use and refinement of operating procedures that support standardising, monitoring and controlling operational activities (Meyr and Stadtler, 2015; Gligor and Holcomb, 2012; Svahn and Westerlund, 2007). This type of network is characterised by highly structured coordination mechanisms, standardised business processes and tight inter-firm processes. Such arrangements are typically found in and managed through dyadic relationship arrangements, often around a focal firm, and through hierarchical structures and contracts. Information technology (IT) enables and enhances the efficiency of such processes (Qamar et al., 2018; Chi and Holsapple, 2005). Thus, efficient SCNs require exploitation knowledge capabilities. This research proposes how exploitation knowledge capabilities can be developed in efficient SCNs.

Firstly, it is argued here that exploitation knowledge capabilities must match market and operational requirements. Of note is that, while all organisations need both knowledge exploitation and knowledge exploration capabilities to survive (Stettner and Lavie, 2014), in organisations performing in stable environments, knowledge exploitation plays a principal role and knowledge exploration plays a supporting role. Knowledge capabilities differ significantly when organisations strive for efficiencies, as opposed to knowledge capabilities relating to responsiveness or innovation (López-Nicolás and Meroño-Cerdán, 2011). In industries where demand and supply are stable, e.g. some consumer product categories 
and commodities, SCN partners focus on continuously improving process efficiencies by standardising inter-organisational processes and conforming to rules and procedures represented by codified knowledge.

Secondly, codified knowledge is found to be the building block of standard business processes (Hansen et al., 1999). Therefore, organisations attempt to codify knowledge that can be explained (Pillai and Min, 2010). In SCNs, knowledge is codified through the elaboration of standard business processes to improve efficiency. Transactional data used in supply chains is codified and shared between supply chain partners and employees so that the efficiency of the supply chains can be enhanced (Bhosale and Kant, 2016). Thus, it is proposed that:

Proposition 1. Codified knowledge is the basis for developing exploitation knowledge capability in efficient SCNs.

Additionally, we argue there is a relationship between single-loop learning, exploitation capabilities and efficiency. Single-loop learning, according to the founding fathers of this concept (Argyris and Schön, 1978), refers to error detection and correction by applying rules/heuristics to well-known operational issues. Exploitation refers to organisational activities aiming at reuse refinement and extension of existing knowledge, routines and capabilities (Gupta et al., 2006; Wilden et al., 2018).

It is therefore possible to say that single-loop learning is a key mechanism that supports the generation and maintenance of exploitation capabilities (Vera et al., 2011). Because knowledge embedded in existing routine heuristics and problem-solving activities (e.g. quality management tools) is already codified, it can be used/reused/diffused at low cost. In turn, this supports incremental, corrective operational improvements that enable efficiency gains - increased quality and lower costs. Hence, the exploitation of organisational capabilities facilitated by single-loop learning suits organisations performing in stable markets/contexts offering standard products/services since they usually compete on price (Garcia-Morales, et al., 2006). This can be summarised as:

Proposition 2. Single-loop learning sustains the exploitation of knowledge in efficient SCNs. 
Feedback learning processes promote organisational efficiency by applying existing (institutionalised) knowledge, from the organisational level to the individual level, passing through group levels (via interpreting and integrating) (Crossan et al., 2011). Recurrent feedback learning processes promote organisational efficiency by correcting operational errors on the spot, monitoring and controlling operational processes. The outcome of this process is an incremental improvement in operations via the application/re-use of rules/heuristics (knowledge exploitation), which in turn supports efficiency in organisations (Jones and Macpherson, 2006). The use of Enterprise Resource Planning modules between partners in an SCN illustrates this situation. Suppliers performing in stable environments dealing with mostly standard products integrate their business processes through sharing/diffusing codified knowledge via Enterprise Resource Planning systems. In the partner organisation, people interpret and apply received codified knowledge to improve/update their existing organisational processes. Thus, it is proposed:

Proposition 3. Feedback learning processes support exploitation knowledge capability in efficient SCNs.

The forecasting and planning processes in efficient SCNs provide an example of the knowledge exploitation capability. Typically, demand planning, forecasting and master planning processes are well defined and highly formalised within and across company boundaries. Sales teams forecast based on historical data (codified knowledge) and disseminate forecast information to other teams (e.g. operations, procurement and finance) through their Enterprise Resource Planning systems. Sales teams also share those forecasts with their inter-firm partners, such as logistics service providers, to guide the supply chain activities in the network. Because forecasts of sales, operations, procurement and finance are codified knowledge, transferring this knowledge to partners is simple and low-cost.

\subsection{Knowledge capabilities required by collaborative supply chain networks}

As global supply chains have become increasingly demand-driven, SCN partners have moved beyond the efficiency-seeking model. They collaborate in order to better respond to customer needs and to build advanced, and often idiosyncratic, supply chain solutions (Jimenez-Jimenez 
et al., 2019). Collaborative networks involve the simultaneous and structured coordination of activities. A focal company often sets the standards, rules and objectives (Meyr and Stadtler, 2015). Therefore, organisational hierarchies and contracts are replaced by collaborative capabilities based on joint technology platforms, process alignment, joint decision-making and common supply chain metrics.

In collaborative SCNs, access to specialised, idiosyncratic knowledge held by partner companies is essential. Firms collaborate because SCN members have heterogeneous skills and knowledge, which are the result of cumulative learning (Lopez and Esteves, 2013). Collaborative SCNs encompass the use of structured coordination activities among network members. The progression from exploitation to exploration requires the development of absorptive capacities, that strengthen the SCN's capability to manage knowledge and learning (Cohen and Levinthal, 1990; Lane et al., 2006). During deployment of knowledge-sharing mechanisms, meanings are reinterpreted, stabilised and agreed on by SCN partners (Lavie et al., 2011).

According to Hult et al. (2007), SCNs achieve performance improvements through collaboration and the requisite exploration knowledge capabilities. Such knowledge capabilities match the operational requirements of collaborative SCNs, since knowledge sharing and learning are catalysts to realign the needs of emerging conditions in the market and develop new market trajectories (Stevenson and Spring, 2009). For example, consumer packaged goods companies extend their supply chains to better integrate information, process and product flows. The use of point-of-sales information in a collaborative supply chain allows for process improvements, improved responsiveness, and product development. These activities, however, are solely possible due to trusted relationships developed over time as well as to the knowledge sharing and learning capabilities of the network.

Relational and somatic tacit types of knowledge are prevalent in collaborative SCNs seeking performance improvements by better coordinating network activities, integrating processes, sharing knowledge and pursuing experimentation (Svahn and Westerlund, 2007). Due to its idiosyncratic nature, managing tacit knowledge appropriately in collaborate supply chains is important. Because tacit knowledge is situated, relational and practice-based (Tsoukas, 2011), it is difficult to imitate or acquire (McEvily and Marcus, 2005). Relational and/or somatic tacit knowledge are the forms of tacit knowledge that enable cross-network operational flexibility to be achieved. This is because relational tacit 
knowledge involves knowing who to talk to and somatic tacit knowledge denotes personality characteristics and competences that support crossnetwork interaction, communication and understanding. Thus, it is proposed:

Proposition 4. Relational and somatic tacit knowledge are the basis for knowledge exploration capability in collaborative SCNs.

Double-loop learning is necessary in order to search for new solutions to changing problems and opportunities. As per Fynes et al. (2005), new product design and development in SCN requires double-loop learning. "Double-loop learning, via processes of exploration, questioning and challenging existing knowledge, can eventually lead to new knowledge creation" (Gosling et al., 2016, p. 1466). Double-loop learning focuses on modifying individual or team behaviour based on critical reflection of current actions, thus leading to effective performance in SCNs (Ramish and Aslam, 2016). Double-loop learning goes beyond single-loop learning and generates new organisational practices and processes (Spicer and Sadler-Smith, 2006; Thomas et al., 2017). In collaborative supply chains, it is important to develop double-loop learning capabilities so that the supply chain partners can learn from each other and enhance supply chain processes. Thus, it is proposed:

\section{Proposition 5. Double-loop learning dominates knowledge exploration capabilities in collaborative SCNs.}

SCNs can enhance the level of market knowledge creation, operational efficiency and performance by building on absorptive capacities to acquire, assimilate, transform and exploit information from SCN partners (Liu et al., 2013; Malhotra et al., 2005). Feed-forward learning processes support exploration-oriented activities by promoting search and adaptation of new knowledge from and to SCN partners (Liu et al., 2013; Malhotra et al., 2005). It enhances the capabilities of collaborative supply chains by reducing the reactive time and providing decisionmakers with leading performance data (da Piedade Francisco et al., 2012). Feed-forward learning (Crossan et al., 2011) encompasses individuals (intuiting) detecting an error/gap or improvement opportunity based on past experience (Sun and Anderson, 2010), acquiring new external information from the collaborative supply chain partners, and groups interpreting gaps/errors to determine a course of action and address the 
issue (Lionzo and Rossignoli, 2013). The integration process translates the shared understanding of the group to the organisational level. During the institutionalisation process, new knowledge is embedded in the organisational structures and processes (Bell et al., 2014). Thus, the feedforward learning process supports both knowledge creation and knowledge acquisition (i.e. knowledge exploration activities), which support new product development, and product and process innovations in collaborative SCNs. It is therefore proposed:

Proposition 6. Feed-forward learning processes support knowledge exploration capabilities in collaborative SCNs.

Next, we explore knowledge capabilities in agile SCNs.

\subsection{Knowledge capabilities required by agile supply chain networks}

Agile SCNs are open and adaptive networks characterised by a flexible structure, an evolving configuration with formal and informal arrangements and goals that drive the decisions of network partners (Christopher, 2000, 2012). These networks tend to have significant levels of complexity due to: (i) the number of network members whose interactions are likely to create uncertainty in the network; (ii) informally coordinated activities with a resulting uncertainty of network members' actions (Lambe et al., 2000); and (iii) the pluralistic nature of the network partners with different power positions, priorities and goals (Choi et al., 2001; Wycisk et al., 2008). Agility in networks requires integrating alertness to changes - that is, recognising opportunities and challenges — with the capability to assemble resources of multiple partners in response to such changes in a timely, flexible, affordable and relevant manner (Li et al., 2008).

Ambidextrous knowledge capability is associated with achieving alignment and adaptability (Gupta et al., 2006; Kortmann et al., 2014). It provides a theoretical perspective for explaining organisational learning and performance improvement in agile SCNs (Lee and Rha, 2016). Ambidextrous knowledge capabilities involve developing knowledge exchange capabilities that aim to acquire, analyse and distribute tactical and strategic information, as well as integrating capabilities that involve applying organisational mechanisms to share tacit knowledge among 
SCN members (Tracey et al., 2005; Blome et al., 2013). Agile SCNs are adaptive networks characterised by a low degree of structure, dynamic configuration and situational decisions by network partners, as opposed to procedural goals and metrics. Empirical research on interorganisational alliances has found that ambidextrous networks develop a complementary and balanced association between the application of existing knowledge (exploitation) and the search for new knowledge (exploration) across organisational domains, rather than focusing on one orientation at the expense of another (Kristal et al., 2010). Lavie et al. (2011), for example, note that ambidextrous organisations pursue exploration in research and development functions and exploitation in marketing functions. Rather than using only existing knowledge, SCN partners generate new knowledge so that the network's performance can be enhanced (Cox et al., 2001; Wu, 2008). Because of the dynamic and adaptive nature of agile SCNs, the level of complexity of both the knowledge and the way to share it among the partners tends to be high. This is due to increasing environmental uncertainty, a large number of network members and the different network partners' power positions, priorities and goals (Lambe et al., 2000; Choi et al., 2001; Håkansson and Persson, 2004; Wycisk et al., 2008; Sabri, 2019). Therefore, the agile SCN uses codified, relational tacit, somatic tacit and collective tacit knowledge to cope with uncertainty and complexity of network activities. A number of recent studies confirm the relationship between agile SCNs and their need for comprehensive tacit knowledge exchange, for example for the maritime industries (Kalogeraki et al., 2018) and the electronics industry (Tse et al., 2016). Based on the current state of academic discourse and evidence from field studies, we present the following proposition:

Proposition 7. Comprehensive tacit knowledge (i.e. relational, somatic and collective tacit knowledge) and codified knowledge support ambidextrous knowledge capabilities in agile SCNs.

Since agile SCNs demand both efficiency and flexibility, learning modes in agile SCNs go beyond single- and double-loop learning. Deutero learning involves understanding the context in which specific consequences emerged in order to adapt behaviours and apply adequate actions. Thus, deutero-learning helps agile networks to deal simultaneously with efficiency and flexibility. According to Visser (2007, p. 660), “through their repeated experience with contingencies of reinforcement, individuals learn to discern characteristic patterns of conditioning in the various 
relationships between themselves and someone or something else, and they learn to adapt their behaviour in response to those patterns". Argyris and Schön (1996) call this meta-learning - a process by which people reflect on the conditions under which single- and double-loop learning takes place to develop new insights into how to improve the whole learning process; that is, how to improve single-loop and double-loop learning, as well as switching to and from single- to double-loop learning in complex situations (Snell et al., 2013).

Empirical research (Kristal et al., 2010; Dwayne et al., 2012) supports the view that an ambidextrous supply chain strategy (simultaneous quest of exploitation and exploration capabilities) leads to superior business performance; that is, it helps to leverage external sources of knowledge to build internal competencies by generating organisational capabilities to achieve, at once, quality, cost and flexibility. Based on this argument, it follows that:

Proposition 8. Deutero-learning supports the ambidextrous knowledge capabilities in agile SCNs.

Feedback and feed-forward learning processes help to address agile SCNs' need for the simultaneous development of exploitation and exploration capabilities - ambidexterity. In feed-forward learning, individual, team and network learning originate from individual insights, joint understanding through collaboration between network members (groups) and, through the integration of the knowledge generated in this process into the organisation's established routines (Crossan et al., 2011). This means that feed-forward processes are learning mechanisms that promote search and adaptation of new knowledge/solutions to new problems - that is, support the generation of exploration capabilities. Feed-forward learning is an emergent, dynamic and often non-linear process. Therefore, it responds to unpredictable and unanticipated demands that agile SCNs are faced with (e.g. Van Wijk et al., 2011). In contrast, because feedback learning involves the application of institutionalised knowledge from the organisational and group level to individuals (Crossan et al., 2011), it promotes refinement and improvement of existing operations; that is, it backs exploitation capabilities.

While these two learning processes and organisational capabilities are different and suitable for different purposes, a key aspect that agile SCNs need to address is how to apply them simultaneously. Recent studies have suggested that adopting a strategy to explore in one domain and 
exploit in another domain of the SCN enhances the performance of the whole SCN (e.g. Lavie et al., 2011; Stettner and Lavie, 2014). Thus, it is proposed:

Proposition 9. Both feedback and feed-forward learning processes support ambidextrous knowledge capabilities in agile SCNs.

The following section synthesises the discussion and provides suggestions for the application of the taxonomy for practitioners and researchers.

\section{Discussion and Conclusions}

This paper examined three types of knowledge capabilities required for three archetypical SCNs. The authors explained and justified the main building blocks of the taxonomy (what), the main connections among related elements (how), and the general underlying logic behind the main elements of the taxonomy (why) (Whetten, 1989).

Before presenting research contributions, practical implications and limitations of the framework, it is necessary to make two clarifications. First, this framework is not normative. That is, because the discussed SCN types and the associated knowledge capabilities are conceptual archetypes, it is expected that, in reality, practitioners will find combinations of SCN types that demand the deliberate customisation of knowledge capabilities. Second, since knowledge capabilities are path-dependent (i.e. past learning shapes future learning; Saenz et al., 2014), SCN managers need to be aware that the deployment of exploitation capabilities is a condition for the deployment of exploration knowledge capabilities. Similarly, the deployment of ambidextrous knowledge capabilities requires the deployment of both exploitation and exploration capabilities.

This conceptual taxonomy has two main theoretical implications. First, it adds to the knowledge capabilities literature (Singh and Dalcher, 2011; Pandey and Dutta, 2013; Nielsen, 2006; Denford, 2013) since it is the first taxonomy that contextualises knowledge capability to requisite 
supply chain types. Rather than assuming universal knowledge capabilities for generic SCNs, this taxonomy shows how knowledge attributes of SCNs are strongly associated with the type of network and the context in which the network evolves. Our research on knowledge capabilities in SCNs accounts for contextual aspects that affect the structure and processes of knowledge capabilities. For example, our conceptual framework considers findings from studies that have identified causal relationships between knowledge and SCNs' performance (Marra et al., 2016); findings about how SCN partners create, transfer and exchange knowledge (Alle, 2000; Lusch, 2011; Samuel et al., 2011); supports the design of governing principles of KM in organisations (Desouza et al., 2003) and; complements other KM typologies (Bolisani and Bratianu, 2017). We achieve this by addressing how context affects knowledge attributes and its associated learning processes in different SCNs types.

Second, this taxonomy adds to supply chain theory by differentiating knowledge capabilities associated with distinct types of SCNs (Teece, 2007; Cohen and Levinthal, 1990; Zahra and George, 2002). This, in turn, complements SCN competency (c.f. Spekman et al., 2002), SCN coordination and integration (Yu et al., 2013) and supply chain fit (Sabri, 2019; Rojo et al., 2016) studies, as they are closely related to how individual and organisational learning mechanisms are deployed in SCNs. Moreover, this study contributes to the body of knowledge in the absorptive capacity literature - the need to be explicit about the type of knowledge being absorbed (Volberda et al., 2010).

In practical terms, this taxonomy has utility — a key element of good theory (Van de Ven, 1989). It provides practical insights for managerial decision-making regarding how to structure and align knowledge capabilities to a particular type of SCN (Lytras and Pouloudi, 2006). This means this taxonomy can help SCN managers to: (i) acknowledge the particular type of network they are involved with, (ii) discuss with other network partners the properties of the network, and (ii) deliberately build knowledge capabilities that match the needs of the network. For example, efficient SCNs are driven by the supply chain partners' focus on cost-efficiencies, steady demand patterns, tightly integrated and rigid information flows, and standardised processes and procedures across the network. Agile SCNs, on the other hand, are characterised by delivering customer-centric solutions, unpredictable demand and volatile markets and ad hoc approaches to delivering products and services. Once the prevailing type of the SCN has been determined, the taxonomy supports managers to develop requisite knowledge capabilities. Because there are no two identical networks (e.g. an efficient SCN in the airline industry is different from an efficient SCN in the fast-food industry), it is necessary to recognise the particular features of the SCN in order to fine-tune knowledge requirements to network characteristics. 
Next, using the taxonomy, managers can deploy organisational policies and processes that support specific learning modes and learning processes and cope with the SCN's prevailing knowledge orientation. For example, in efficient SCNs, managers need to focus on establishing single-loop learning modes — such as standard operating procedures combined with the intensive use of IT — to successfully deal with repetitive tasks that entail codified forms of knowledge. Likewise, if the SCN is collaborative, managers need to concentrate their efforts on deploying organisational policies and processes to support: (i) double-loop learning modes that allow individual and group problem-solving, and (ii) feedforward processes (intuiting and interpreting at the individual level, integrating at the group level and institutionalising at the organisational level) to cope with relational, somatic and collective tacit forms of knowledge.

Though the study makes several theoretical and practical contributions, it has a few limitations that need to be acknowledged. The taxonomy and the propositions developed in this research are conceptual. Thus, research may need to address the validity of the suggested taxonomy and propositions in different contexts to confirm the taxonomy's applicability. Researchers may compare SCNs of the same type deployed in different

industry sectors, or they can analyse distinct networks in the same industry. By detailing how knowledge capabilities evolve in SCNs, the taxonomy and propositions would strengthen their explanatory power. Additionally, knowledge capabilities and SCN types were derived based on two established bodies of research, thus it is necessary to acknowledge that additional categories might exist. Then, a research opportunity opens to investigate additional knowledge capabilities in new forms of network organizations. For example, little is known about knowledge capabilities in knowledge-intensive network organizations such as financial technology banks, gig-economy firms (e.g. Uber, Airbnb and Trivago) and global social enterprises.

\section{References}

Allee, V. (2000), "Reconfiguring the value network", Journal of Business Strategy, Vol. 21 No. 4, pp. 36-39.

Alvesson, M. and Sandberg, J. (2013), Constructing research questions: Doing interesting research. Sage. 
Antonacopoulou, E. and Chiva, R. (2007), “The social complexity of organisational learning: the dynamics of learning and organizing", Management Learning, Vol. 38 No. 3, pp. 277-295.

Argote, L. and Miron-Spektor, E. (2011), “Organizational learning: From experience to knowledge”, Organization Science, Vol. 22, pp. 11231137.

Argyris, C. and Schön, D. (1978), Organisational Learning: A Theory of Action Approach, Addison-Wesley, Reading, Massachusetts.

Argyris, C. and Schön, D. (1996): Organizational learning II: Theory, method and practice Addison-Wesley, Reading, Massachusetts.

Attia, A. and Essam Eldin, I. (2018), "Organizational learning, knowledge management capability and supply chain management practices in the Saudi food industry”, Journal of Knowledge Management, Vol. 22 No. 6, pp. 1217-1242.

Bell, J. E., Bradley, R. V., Fugate, B. S. and Hazen, B. T. (2014), "Logistics information system evaluation: Assessing external technology integration and supporting organizational learning”, Journal of Business Logistics, Vol. 35 No. 4, pp. 338-358.

Bhosale, V.A. and Kant, R. (2016), “An integrated ISM fuzzy MICMAC approach for modelling the supply chain knowledge flow enablers”, International Journal of Production Research, Vol. 54 No. 24, pp. 7374-7399.

Blome, C., Schönherr, T. and Eckstein, D. (2014), "The impact of knowledge transfer and complexity on supply chain flexibility: a knowledgebased view", International Journal of Production Economics, Vol. 147, pp. 307-316.

Blome, C., Schönherr, T. and Rexhausen, D. (2013), "Antecedents and enablers of supply chain agility and its effect on performance: a dynamic capabilities perspective", International Journal of Production Research, Vol. 51 No. 4, pp. 1295-1318.

Bolisani, E. and Bratianu, C. (2017), "Knowledge strategy planning: an integrated approach to manage uncertainty, turbulence, and dynamics." Journal of Knowledge Management, Vol. 21 No. 2, pp. 233-253.

Bontis, N., Crossan, M.M. and Hulland, J. (2002), "Managing an organisational learning system by aligning stocks and flows", Journal of Management Studies, Vol. 39 No. 4, pp. 437-469.

Cambra-Fierro, J., Florin, J., Perez, L. and Whitelock, J. (2011), "Inter-firm market orientation as antecedent of knowledge transfer, innovation and value creation in networks", Management Decision, Vol. 49 No. 3, pp. 444-467. 
Capó-Vicedo, J., Mula, J. and Capó, J. (2011), “A social network-based organizational model for improving knowledge management in supply chains”, Supply Chain Management: An International Journal, Vol. 16 No. 5, pp. 379-388.

Cerchione, R. and Esposito, E. (2016), “A systematic review of supply chain knowledge management research: state of the art and research opportunities", International Journal of Production Economics, Vol. 182, pp. 276-292.

Chi, L. and Holsapple, C.W. (2005), "Understanding computer-mediated interorganisational collaboration: a model and framework", Journal of Knowledge Management, Vol. 9 No. 1, pp. 53-75.

Choi, T.Y., Dooley, K.J. and Rungtusanatham, M. (2001), "Supply networks and complex adaptive systems: control versus emergence”, Journal of Operations Management, Vol. 19 No. 3, pp. 351-366.

Choo, C.W. and Bontis, N. (eds) (2002), The Strategic Management of Intellectual Capital and Organizational Knowledge: A Collection of Readings, Oxford University Press, Incorporated, Cary.

Christopher, M. (2000), “The agile supply chain: competing in volatile markets”, Industrial Marketing Management, Vol. 29 No. 1, pp. 37-44.

Christopher, M. (2012), "Managing supply chain complexity: identifying the requisite skills", Supply Chain Forum, Vol. 13 No. 2 , pp. 4-9.

Christopher, M. and Peck, H. (2004), "Building the resilient supply chain", International Journal of Logistics Management, Vol. 15 No. 2 , pp. 1-14.

Cohen, W.M. and Levinthal, D.A. (1990), “Absorptive capacity: a new perspective on learning and innovation", Administrative Science Quarterly, Vol. 35, pp. 128-152.

Collins, H. (2010), Tacit and Explicit Knowledge, Chicago University Press, Chicago, IL.

Corley, K.G. and Gioia, D.A. (2011) "Building theory about theory building: what constitutes a theoretical contribution?", Academy of Management Review, Vol. 36 No. 1, pp. 12-32.

Cox, A., Sanderson, J. and Watson, G. (2001), "Supply chains and power regimes: toward an analytic framework for managing extended networks of buyer and supplier relationships", Journal of Supply Chain Management, Vol. 37 No. 1, pp. 28-35. 
Crossan, M.M., Maurer, C.C. and White, R.E. (2011), "Reflections on the 2009 AMR decade award: do we have a theory of organizational learning?", Academy of Management Review, Vol 36, pp. 446-460.

da Piedade Francisco, R., Azevedo, A. and Almeida, A. (2012). "Alignment prediction in collaborative networks", Journal of Manufacturing Technology Management, Vol. 23 No. 8, pp. 1038-1056.

Denford, J. (2013) “Building knowledge: developing a knowledge-based dynamic capabilities typology”, Journal of Knowledge Management, Vol. 17 No. 2, pp. 1367-3270.

Desouza, K.C., Chattaraj, A. and Kraft, G. (2003), "Supply chain perspectives to knowledge management: research propositions", Journal of Knowledge Management, Vol. 7 No. 3, pp. 129-138.

Doty, D.H. and Glick, W.H. (1994), "Typologies as a unique form of theory building: toward improved understanding and modeling”, Academy of Management Review, Vol. 19 No. 2, pp. 230-251.

Durst, S. and Evangelista, P. 2018. "Exploring knowledge management practices in third-party logistics service providers", VINE Journal of Information and Knowledge Management Systems, Vol. 48 No. 2, pp. 162-177.

Dwayne Whitten, G., Green Jr, K.W. and Zelbst, P.J. (2012), “Triple-A supply chain performance”, International Journal of Operations and Production Management, Vol. 32 No. 1, pp. 28-48.

Freeze, R. D. and Kulkarni, U. (2007), "Knowledge management capability: defining knowledge assets", Journal of Knowledge management, Vol. 11 No. 6, pp. 94-109.

Freeze, R. D. and Kulkarni, U. (2007). "Knowledge management capability: defining knowledge assets", Journal of Knowledge management, Vol. 11 No. 6, pp. 94-109.

Fynes, B., Voss, C. and de Búrca, S. (2005), "The impact of supply chain relationship quality on quality performance", International Journal of Production Economics, Vol. 96 No. 3, pp. 339-354.

Garcia-Morales, V.J., Lorens-Montes, F.J. and Verdu-Jover, A.J. (2006), “Organisational learning categories: their influence on organisational performance", International Journal of Innovation and Learning, Vol. 3 No. 5, pp. 518-536. 
Gligor, D.M. and Holcomb, M.C. (2012), "Understanding the role of logistics capabilities in achieving supply chain agility: a systematic literature review", Supply Chain Management: An International Journal, Vol. 17 No. 4, pp. 438-453.

Gold, A. H., Malhotra, A. and Segars, A. H. (2001). "Knowledge management: An organizational capabilities perspective", Journal of management information systems, Vol. 18 No. 1, pp. 185-214.

Gosling, J., Jia, F., Gong, Y. and Brown, S. (2016), "The role of supply chain leadership in the learning of sustainable practice: toward an integrated framework", Journal of Cleaner Production, Vol. 137, pp. 1458-1469.

Gupta, A.K., Smith, K.G. and Shalley, C.E. (2006), "The interplay between exploration and exploitation”, Academy of Management Journal, Vol. 49 No. 4, pp. 693-706.

Håkansson, H. and Persson, G. (2004), "Supply chain management: the logic of supply chains and networks", International Journal of Logistics Management, Vol. 15 No. 1, pp. 11-26.

Hansen M.T., Nohria, N. and Tierney, T. (1999), “What's your strategy for managing knowledge?”, Harvard Business Review, Vol. 77 No. 2 , pp. 106-116.

Hislop, D. (2005), Knowledge Management in Organizations, Oxford University Press, Oxford.

Hult, G.T.M., Ketchen, D.J. and Arrfelt, M. (2007), "Strategic supply chain management: improving performance through a culture of competitiveness and knowledge development”, Strategic Management Journal, Vol. 28 No. 10, pp. 1035-1052.

Jimenez-Jimenez, D., Martínez-Costa, M. and Sanchez Rodriguez, C. (2019), "The mediating role of supply chain collaboration on the relationship between information technology and innovation”, Journal of Knowledge Management, Vol. 23 No.3, pp. $548-567$.

Jones, O. and Macpherson, A. (2006), "Inter-organizational learning and strategic renewal in SMEs: extending the 4I framework", Long Range Planning, Vol. 39 No. 2, pp. 155-175.

Kalogeraki, E.M., Apostolou, D., Polemi, N. and Papastergiou, S. (2018), "Knowledge management methodology for identifying threats in maritime/logistics supply chains", Knowledge Management Research and Practice, Vol. 16 No. 4, pp. 508-524. 
Kortmann, S., Gelhard, C., Zimmermann, C. and Piller, F.T. (2014), "Linking strategic flexibility and operational efficiency: the mediating role of ambidextrous operational capabilities”, Journal of Operations Management, Vol. 32 No. 7-8, pp. 475-490.

Kovács, G. and Spens, K. (2005), “Abductive reasoning in logistics research”, International Journal of Physical Distribution and Logistics Management, Vol. 35 No. 2, pp. 132-144.

Kristal, M., Huang, X. and Roth, A. (2010), “The effect of an ambidextrous supply chain strategy on combinative competitive capabilities and business performance", Journal of Operations Management, Vol. 28, pp. 415-425.

Lambe, C.J., Spekman, R.E. and Hunt, S.O. (2000), "Interimistic relational exchange: conceptualization and propositional development". Journal of the Academy of Marketing Science, Vol. 28 No.2, pp. 212-226.

Lane, P., Koka, S. and Pathak, S. (2006), "The reification of absorptive capabilities", Academy of Management Review, Vol. 31 No. 4 , pp. 833863.

Lavie, D., Kang, J. and Rosenkopf, L. (2011), "Balance within and across domains: the performance implications of exploration and exploitation in alliances", Organization Science, Vol. 22 No. 6, pp. 1517-1538.

Lee, S.M. and Rha, J.S. (2016), “Ambidextrous supply chain as a dynamic capability: building a resilient supply chain”, Management Decision, Vol. 54, No. 1, pp. 2-23.

Li, X., Chung, C., Goldsby, T.J. and Holsapple, C.W. (2008), “A unified model of supply chain agility: the work-design perspective”, International Journal of Logistics Management, Vol. 19 No. 3, pp. 408-435.

Lin, C., Hung, H.-C., Wu, J.-Y. and Lin, B. (2002), “A knowledge management architecture in collaborative supply chain”, Journal of Computer Information Systems, Vol. 42 No. 5, pp. 83-94.

Lionzo, A. and Rossignoli, F. (2013), "Knowledge integration in family SMEs: an extension of the 4I model", Journal of Management and Governance, Vol. 17 No. 3, pp. 583-608.

Liu, H., Ke, W., Wei, K.K. and Hua, Z. (2013). "The impact of IT capabilities on firm performance: the mediating roles of absorptive capacity and supply chain agility", Decision Support Systems, Vol. 54 No. 3, pp. 1452-1462. 
López-Nicolás, C. and Meroño-Cerdán, Á.L. (2011), "Strategic knowledge management, innovation and performance”, International Journal of Information Management, Vol. 31 No. 6, pp. 502-509.

Lopez, V.W.B. and Esteves, J. (2013), “Acquiring external knowledge to avoid wheel re-invention”, Journal of Knowledge Management, Vol. 17 No. 1 , pp. 87-105.

Lusch, R. (2011), “Reframing supply chain management: a service dominant logic perspective”, Journal of Supply Chain Management, Vol. 47 No. 1, pp. 14-18.

Lytras, M.D. and Pouloudi, A. (2006), “Towards the development of a novel taxonomy of knowledge management systems from a learning perspective: an integrated approach to learning and knowledge infrastructures”, Journal of Knowledge Management, Vol. 10, No. 6, pp. 6480.

MacInnis, D.J. (2011), “A framework for conceptual contributions in marketing”, Journal of Marketing, Vol. 75 No. 4, pp. 136-154.

Malhotra, A., Gosain, S. and Sawy, O.A.E. (2005), “Absorptive capacity configurations in supply chains: gearing for partner-enabled market knowledge creation", MIS Quarterly, Vol 29 No. 1, pp. 145-187.

March, J.G. (1991), "Exploration and exploitation in organizational learning”, Organization Science, Vol. 2 No. 1, pp. $71-87$.

Marr, B., Schiuma, G. and Neely, A. (2004), "Intellectual capital-defining key performance indicators for organizational knowledge assets", Business Process Management Journal, Vol. 10 No. 5, pp. 551-569.

Marra, M., Ho, W. and Lee, C. K. M. (2016), "Managing supply chain knowledge-based linkages for improving operational performance", Knowledge Management Research and Practice, Vol. 14 No. 3, pp. 256-269.

McEvily, B. and Marcus, A. (2005), "Embedded ties and the acquisition of competitive capabilities", Strategic Management Journal, Vol. 26 No. 11, pp. 1033-1055.

McIver, D., Lengnick-Hall, C., Lengnick-Hall M. and Ramachandran, I. (2013), "Understanding work and knowledge management from a knowledge-in-practice perspective", Academy of Management Review, Vol. 38 No. 4, pp. 597-620. 
Meyr H. and Stadtler H. (2015), "Types of supply chains”, in Stadtler, H., Kilger, C. and Meyr, H. (Eds.), Supply Chain Management and Advanced Planning, Springer Texts in Business and Economics, Springer, Berlin, Heidelberg.

Nielsen, A. (2006), “Understanding dynamic capability: defining knowledge assets”, Journal of Knowledge management, Vol. 10 No. 4, pp. 5971.

Pandey, S. C. and Dutta, A. (2013), "Role of knowledge infrastructure capabilities in knowledge management", Journal of knowledge management, Vol. 17 No. 3, pp. 435-453.

Pereira, V., Mellahi, K., Temouri, Y., Patnaik, S. and Roohanifar, M. (2018), "Investigating dynamic capabilities, agility and knowledge management within EMNEs-longitudinal evidence from Europe”, Journal of Knowledge Management, Vol. 23 No. 9, pp. $1708-1728$.

Pillai, K.G. and Min, S. (2010), “A firm's capability to calibrate supply chain knowledge — antecedents and consequences”, Industrial Marketing Management, Vol. 39 No. 8, pp. 1365-1375.

Potter, A., Denis, R., Towill, D.R. and Martin, C.M. (2015), "Evolution of the migratory supply chain model", Supply Chain Management: An International Journal, Vol. 20 No. 6, pp. 603-612.

Qamar, A., Hall, M.A. and Collinson, S. (2018), "Lean versus agile production: flexibility trade-offs within the automotive supply chain”, International Journal of Production Research, Vol. 56 No. 11, pp. 3974-3993.

Ramish A. and Aslam H., (2016) "Measuring supply chain knowledge management (SCKM) performance based on double/triple loop learning principle", International Journal of Productivity and Performance Management, Vol. 65 No. 5, pp. 704-722.

Rangachari, P. (2009), “Knowledge sharing networks in professional complex systems”, Journal of Knowledge Management, Vol. 13 No. 3 , pp. 132-145.

Rojo, A., Llorens-Montes, J. and Perez-Arostegui, M.N. (2016), “The impact of ambidexterity on supply chain flexibility fit”, Supply Chain Management: An International Journal, Vol. 21 No. 4, pp. 433-452.

Sabri, Y. (2019), "In pursuit of supply chain fit", International Journal of Logistics Management, Vol. 30 No. 3, pp. 821-844. 
Saenz, M.J., Revilla, E. and Knoppen, D. (2014), "Absorptive capacity in buyer-supplier relationships: empirical evidence of its mediating role", Journal of Supply Chain Management, Vol. 50 No. 2, pp. 18-40.

Samuel, K. E., Goury, M. L., Gunasekaran, A. and Spalanzani, A. (2011), "Knowledge management in supply chain: an empirical study from France", The Journal of Strategic Information Systems, Vol. 20 No. 3, pp. 283-306.

Sappington, J. and Bedford, D. A. (2017), “Assessment of intellectual capital of library and information professionals”. Proceedings of the Association for Information Science and Technology, Vol. 54 No. 1, pp. 798-799

Shapira, Z. (2011), “'I've got a theory paper-do you?': conceptual, empirical, and theoretical contributions to knowledge in the organizational sciences", Organization science, Vol. 22 No. 5, pp. 1312-1321.

Singh, S. B. and Dalcher, D., (2011). "Developing knowledge management capabilities: a structured approach." Journal of Knowledge Management Vol. 15 No. 2, pp. 313-328.

Snell, R., Yi, Z. and Chak,A., (2013) 'Representational predicaments for employees: their impact on perceptions of supervisors' individualized consideration and on employee job satisfaction"” The International Journal of Human Resource Management, Vol. 24 No. 8, pp. 16461670.

Sohrabi, S. and Naghavi, M.S. (2014), "The interaction of explicit and tacit knowledge", paper presented at the International Conference on Intellectual Capital and Knowledge Management and Organisational Learning, United Kingdom.

Spekman, R., Spear, J. and Kamauff, J. (2002), "Supply chain competency: learning as a key component”, Supply Chain Management: An International Journal, Vol. 7 No. 1, pp. 41-55.

Spicer, D. P. and Sadler-Smith, E. (2006), “Organizational learning in smaller manufacturing firms”, International Small Business Journal, Vol. 24 No. 2, pp. 133-158.

Stettner, U. and Lavie, D. (2014), “Ambidexterity under scrutiny: exploration and exploitation via internal organization, alliances, and acquisitions", Strategic Management Journal, Vol. 35 No. 13, pp. 1903-1929. 
Stevenson, M. and Spring, M. (2009), "Supply chain flexibility: an inter-firm empirical study", International Journal of Operations and Production Management, Vol. 29 No. 9, pp. 946-971.

Sun, P.Y. and Anderson, M.H. (2010), “An examination of the relationship between absorptive capacity and organizational learning, and a proposed integration", International Journal of Management Reviews, Vol. 12 No. 2, pp. 130-150.

Svahn, S. and Westerlund, M. (2007), “The modes of supply net management: a capability view”, Supply Chain Management: An International Journal, Vol. 12 No. 5, pp. 369-376.

Teece, D.J. (2007), "Explicating dynamic capabilities: the nature and microfoundations of (sustainable) enterprise performance", Strategic Management Journal, Vol. 28 No. 13, pp. 1319-1350.

Teece, D.J., Pisano, G. and Shuen, A. (2000), “Dynamic capabilities and strategic management”, Strategic Management Journal, Vol. 18 No. 7 , pp. 509-533.

Thomas, A., Dorrington, P., Costa, F., Loudon, G., Francis, M. and Fisher, R. (2017), “Organisational learning capability in SMEs: an empirical development of innovation in the supply chain", Cogent Business and Management, Vol. 4 No. 1.

Timmermans, S. and Tavory, I. (2012), "Theory construction in qualitative research: from grounded theory to abductive analysis", Sociological Theory, Vol. 30 No. 3, pp. 167-186.

Tosey, P., Visser, M. and Saunders, M.N. (2012), “The origins and conceptualizations of 'triple-loop' learning: a critical review”, Management Learning, Vol. 43 No. 3, pp. 291-307.

Tracey, M., Lim, J.-S. and Vonderembse, M.A. (2005), “The impact of supply-chain management capabilities on business performance”, Supply Chain Management: An International Journal, Vol. 10 No. 3, pp. 179-191.

Tse, Y.K., Zhang, M., Akhtar, P. and MacBryde, J. (2016), “Embracing supply chain agility: an investigation in the electronics industry”, Supply Chain Management: An International Journal, Vol. 21 No. 1, pp.140-156.

Tsoukas, H. (2011), "How should we understand tacit knowledge? A phenomenological view”, in Easterby-Smith, M. and Lyles, M.A. (Eds.), Handbook of Organisational Learning and Knowledge Management, John Wiley and Son, Chichester, England. 
Turner, KL and Makhija, NV (2006), "The role of organizational controls in managing knowledge”, Academy of Management Review, Vol. 31 No. 1, pp. 197-217.

Turner, N. and Lee-Kelley, L. (2013), "Unpacking the theory on ambidexterity: an illustrative case on the managerial architectures, mechanisms and dynamics", Management Learning, Vol. 44 No. 2, pp. 179-196.

Van de Ven, A.H. (1989), "Nothing is quite so practical as a good theory", Academy of Management Review, Vol. 14 No. 4, pp. $486-489$.

Van Wijk, R., Van den Bosh, F. and Volberda, H. (2011), “Absorptive capacity: taking stock of its progress and prospects”, in Easterby-Smith, M. and Lyles, M.A. (Eds.), Handbook of Organisational Learning and Knowledge Management, John Wiley and Sons, Chichester, England.

Vera, D., Crossan, M. and Apaydin, M. (2011). “A framework for integrating organizational learning, knowledge, capabilities, and absorptive capacity", in Easterby-Smith, M. and Lyles, M.A. (Eds.), Handbook of Organisational Learning and Knowledge Management, John Wiley and Sons, Chichester, England.

Visser, M. (2007), “Deutero-learning in organisations: a review and a reformulation”, Academy of Management Review, Vol. 32 No. 2 , pp. 659667.

Volberda, H., Foss, N. and Lyles, M. (2010), "Absorbing the concept of absorptive capabilities: how to realize its potential in the organisational field", Organisation Science, Vol. 21 No. 4, pp. 931-951.

Weick, K.E. and Sutcliffe, K.M. (2007), Managing the Unexpected: Resilient Performance in an Age of Uncertainty, $2^{\text {nd }}$ ed., Jossey Bass, San Francisco.

Whetten, D.A. (1989), “What constitutes a theoretical contribution?”, Academy of Management Review, Vol. 14 No. 4, pp. 490-495.

Wilden, R., Hohberger, J., Devinney, T. and Lavie, D. (2018) “Revisiting James March (1991): whither exploration and exploitation?”, Strategic Organization, Vol. 16 No. 3, pp. 352-369.

Wong, W. P. and Wong, K. Y. (2011), "Supply chain management, knowledge management capability, and their linkages towards firm performance", Business Process Management Journal, Vol. 17 No. 6, pp. 940-964.

Wu, C. (2008), “Knowledge creation in a supply chain”, Supply Chain Management: An International Journal, Vol. 13 No. 3, pp. $241-250$. 
Wu, L. and Chen, J. L. (2014), "Knowledge management driven firm performance: the roles of business process capabilities and organizational learning”, Journal of Knowledge Management, Vol. 18 No. 6, pp. 1141-1164.

Wycisk, C., McKelvey, B. and Hülsmann, M. (2008), “'Smart parts' supply networks as complex adaptive systems: analysis and implications”, International Journal of Physical Distribution and Logistics Management, Vol. 38 No. 2, pp. 108-125.

Yadav, M.S. (2010), “The decline of conceptual articles and implications for knowledge development”, Journal of Marketing, Vol. 74 No. 1, pp. 1-19.

Yang, C. and Chen, L. C. (2007), "Can organizational knowledge capabilities affect knowledge sharing behavior?” Journal of information science, Vol. 33 No. 1, pp. 95-109.

Yu, W., Jacobs, M.A., Salisbury, W.D. and Enns, H. (2013), "The effects of supply chain integration on customer satisfaction and financial performance: an organizational learning perspective", International Journal of Production Economics, Vol. 146 No.1, pp. 346-358.

Zahra, S.A. and George, G. (2002), “Absorptive capacity: a review, reconceptualization, and extension”, Academy of Management Review, Vol. 27 No. 2, pp. 185-203. 
Table 3. Types of Knowledge capabilities

\begin{tabular}{|c|c|c|c|}
\hline $\begin{array}{l}\text { Knowledge } \\
\text { Capability }\end{array}$ & Knowledge Orientation & Key Features & Key References \\
\hline \multirow[t]{5}{*}{$\begin{array}{l}\text { Exploitation } \\
(\text { March, 1991) }\end{array}$} & \multirow{5}{*}{$\begin{array}{l}\text { Use of existing (mostly } \\
\text { codified) knowledge and } \\
\text { standard organisational } \\
\text { processes to provide } \\
\text { efficiency/efficacy to the } \\
\text { SCN }\end{array}$} & Focus on codifying knowledge and business processes & $\begin{array}{l}\text { Hansen et al. (1999), Bolisani and Bratianu (2017), Gupta } \\
\text { et al. (2006), Pillai and Min (2010), Wilden et al. (2018) }\end{array}$ \\
\hline & & Efficiency-focused KM strategy & $\begin{array}{l}\text { Choi and Lee (2002), Bhosale and Kant (2016), Garcia- } \\
\text { Morales (2006), Zhang, He, and Lee (2008) }\end{array}$ \\
\hline & & High emphasis on KM infrastructure capabilities & Singh and Dalcher (2011) \\
\hline & & $\begin{array}{l}\text { Top-down transmission of managerial knowledge } \\
\text { supports exploitation activities }\end{array}$ & Mom et al. (2007) \\
\hline & & Intensive use of IT (system-oriented KM strategy) & Teece (2007), López-Nicolás and Meroño-Cerdán (2011) \\
\hline \multirow[t]{6}{*}{$\begin{array}{l}\text { Exploration } \\
(\text { March, 1991) }\end{array}$} & \multirow{6}{*}{$\begin{array}{l}\text { Search, acquisition and } \\
\text { learning of new } \\
\text { knowledge to provide } \\
\text { flexibility to the SCN }\end{array}$} & Focus on people-to-people sharing knowledge & $\begin{array}{l}\text { Hansen et al. (1999), Bolisani and Bratianu (2017), Lopez } \\
\text { and Esteves (2013) }\end{array}$ \\
\hline & & $\begin{array}{l}\text { KM strategy is focused on balanced efficiency and } \\
\text { effectiveness }\end{array}$ & Choi and Lee (2002) \\
\hline & & $\begin{array}{l}\text { Less emphasis on KM infrastructure capabilities (e.g. } \\
\text { IT and process automation) }\end{array}$ & Singh and Dalcher (2011) \\
\hline & & $\begin{array}{l}\text { Bottom-up and horizontal transmission of managerial } \\
\text { knowledge supports exploration activities }\end{array}$ & Mom et al. (2007) \\
\hline & & Human-oriented KM strategy & Teece (2007), López-Nicolás and Meroño-Cerdán (2011) \\
\hline & & $\begin{array}{l}\text { SCN can enhance the operational efficiency and the } \\
\text { level of market knowledge creation by building } \\
\text { absorptive capacity to acquire, assimilate, transform } \\
\text { and exploit information from SCN partners }\end{array}$ & $\begin{array}{l}\text { da Piedade Francisco, Azevedo, \& Almeida, (2012), Hult, } \\
\text { Ketchen, and Arrfelt (2007), Malhotra, Gosain, and Sawy } \\
\text { (2005), Liu, Ke, Wei, and Hua (2013) }\end{array}$ \\
\hline Ambidextrous & $\begin{array}{l}\text { Ability to balance } \\
\text { knowledge orientation }\end{array}$ & $\begin{array}{l}\text { Ambidexterity is dynamic as SCN configurations } \\
\text { change over time }\end{array}$ & Raisch et al. (2009) \\
\hline
\end{tabular}




\begin{tabular}{|c|c|c|c|}
\hline $\begin{array}{l}\text { Knowledge } \\
\text { Capability }\end{array}$ & Knowledge Orientation & Key Features & Key References \\
\hline \multirow[t]{6}{*}{$\begin{array}{l}\text { (Lavie et al., } \\
\text { 2011) }\end{array}$} & \multirow{6}{*}{$\begin{array}{l}\text { (between exploitation and } \\
\text { exploration) to respond to } \\
\text { dynamic and } \\
\text { unanticipated changes in } \\
\text { markets and contexts }\end{array}$} & $\begin{array}{l}\text { SCN can either specialise or balance exploration and } \\
\text { exploitation orientations }\end{array}$ & $\begin{array}{l}\text { Blome et al. (2013), Gupta et al. (2006), Kortmann et al. } \\
\text { (2016), Kristal et al. (2010), Lavie et al. (2011), Raisch et } \\
\text { al. (2009) }\end{array}$ \\
\hline & & Dynamic KM strategy & $\begin{array}{l}\text { Choi and Lee (2002), López-Nicolás and Meroño-Cerdán } \\
\text { (2011), Cox, Sanderson, and Watson (2001) }\end{array}$ \\
\hline & & Continuous (re)aligment & Senge, (2006), Teece (2007) \\
\hline & & $\begin{array}{l}\text { SCN collaboration (trust, openness, shared risks and } \\
\text { rewards) is crucial for both exploration and } \\
\text { exploitation }\end{array}$ & Holweg et al. (2005) \\
\hline & & $\begin{array}{l}\text { SCN ambidexterity demands: (i) integration of internal } \\
\text { and external operations and knowledge processes, and } \\
\text { (ii) alignment of demand patterns and product } \\
\text { characteristics }\end{array}$ & Raisch et al. (2009), Holweg et al. (2005) \\
\hline & & $\begin{array}{l}\text { Balancing exploration and exploitation across } \\
\text { domains, rather than within domains, supports both } \\
\text { strategic flexibility and operational efficiency }\end{array}$ & $\begin{array}{l}\text { Kortmann et al. (2014), Kristal et al. (2010), Stettner and } \\
\text { Lavie (2014), Lavie, et al. (2011) }\end{array}$ \\
\hline
\end{tabular}


Table 4. Types of supply chain networks

\begin{tabular}{|c|c|c|c|}
\hline SCN Type & Concept & Key features & References \\
\hline \multirow[t]{3}{*}{ Efficient } & \multirow{3}{*}{$\begin{array}{l}\text { Focus on efficiency. } \\
\text { Adequate in stable } \\
\text { markets/contexts. }\end{array}$} & $\begin{array}{l}\text { SCNs integrate dispersed knowledge to cope with } \\
\text { operational uncertainty and knowledge asymmetries }\end{array}$ & $\begin{array}{l}\text { Choi and Krause (2006), Yu et al. (2013), Meyr and } \\
\text { Stadtler (2015), Kalogeraki et al. (2018) }\end{array}$ \\
\hline & & $\begin{array}{l}\text { Information flows between SCN partners lead to SCN } \\
\text { efficiency }\end{array}$ & $\begin{array}{l}\text { Corso et al. (2010), Gligor and Holcomb (2012), Bell et al. } \\
\text { (2014), Marra et al. (2016) }\end{array}$ \\
\hline & & $\begin{array}{l}\text { Efficiency of the supply chains is enhanced by } \\
\text { improving employee knowledge, skills and attitudes }\end{array}$ & Jacobides and Winter (2005), Kortmann et al. (2014) \\
\hline \multirow[t]{4}{*}{ Collaborative } & \multirow{4}{*}{$\begin{array}{l}\text { Focus on product, service } \\
\text { and process flexibility. } \\
\text { Adequate in evolving and } \\
\text { advanced } \\
\text { markets/contexts. }\end{array}$} & $\begin{array}{l}\text { Supply chains require managing knowledge and } \\
\text { learning to develop capabilities to adapt to diverse } \\
\text { market needs }\end{array}$ & Spekman et al. (2002), Durst and Evangelista (2018) \\
\hline & & $\begin{array}{l}\text { SCNs that are able to adapt to market conditions } \\
\text { achieve competitive advantage }\end{array}$ & $\begin{array}{l}\text { Desouza et al. (2003), Hult et al. (2007), Saenz et al. } \\
\text { (2014) }\end{array}$ \\
\hline & & $\begin{array}{l}\text { Integration between supply chain partners is required } \\
\text { to enhance KM. Flexibility of the SCNs can be } \\
\text { enhanced by establishing stable links between SCN } \\
\text { partners }\end{array}$ & $\begin{array}{l}\text { Bontis (2002), Lee (2004), Hult et al. (2004), da Piedade } \\
\text { Francisco et al. (2012), Fynes et al. (2005), Thomas et al. } \\
\text { (2017), Jimenez-Jimenez et al. (2019) }\end{array}$ \\
\hline & & $\begin{array}{l}\text { Collaborative supply chains focus on knowledge } \\
\text { relating to product and process flexibility; adequate in } \\
\text { evolving and advanced markets/contexts }\end{array}$ & $\begin{array}{l}\text { Desouza et al. (2003), Svahn and Westerlund (2007), } \\
\text { Dekkers and Bennett (2010), Lopez and Esteves (2013), } \\
\text { Sudhindra et al. (2014), Gosling et al. (2016), Ramish and } \\
\text { Aslam (2016) }\end{array}$ \\
\hline \multirow[t]{3}{*}{ Agile } & \multirow{3}{*}{$\begin{array}{l}\text { Focus on flexibility and } \\
\text { responsiveness to quickly } \\
\text { cope with unanticipated } \\
\text { changes. Adequate in } \\
\text { highly dynamic market } \\
\text { environments. }\end{array}$} & $\begin{array}{l}\text { SCN agility responds to a high level of market } \\
\text { volatility }\end{array}$ & $\begin{array}{l}\text { Li et al. (2008), Christopher (2012), Blome et al. (2014), } \\
\text { Sudhindra et al. (2014), Barrat and Eagle (2017) }\end{array}$ \\
\hline & & $\begin{array}{l}\text { Agile SCNs develop capabilities to adequately manage } \\
\text { (i.e. convert and combine) their knowledge base to } \\
\text { respond to changing market requirements }\end{array}$ & $\begin{array}{l}\text { Christopher (2000), Raisinghani and Meade (2005), } \\
\text { Rangachari (2009), Bolisani and Bratianu (2017) }\end{array}$ \\
\hline & & $\begin{array}{l}\text { Contingencies in dynamic supply chains can be } \\
\text { governed by following KM principles }\end{array}$ & Lopez and Esteves (2013), Blome et al. (2014), Luu (2017) \\
\hline
\end{tabular}




\begin{tabular}{|l|l|l|l|}
\hline SCN Type & Concept & Key features & References \\
\hline & & $\begin{array}{l}\text { A high level of shared information is a key enabler of } \\
\text { supply chain agility }\end{array}$ & $\begin{array}{l}\text { Christopher (2000), Gligor and Holcomb (2012), Dwayne } \\
\text { et al. (2012), Turner and Lee-Kelley (2013), Lee and Rha } \\
(2016)\end{array}$ \\
\cline { 2 - 4 } & $\begin{array}{l}\text { Efficient and sustainable KM strategies are crucial for } \\
\text { managing supply chains in dynamic business } \\
\text { environments }\end{array}$ & $\begin{array}{l}\text { Wu (2008), Lytras and Pouloudi (2006), Raisch et al. } \\
\text { (2009), Rojo et al. (2016), Tse } \text { et al. (2016) }\end{array}$ \\
\hline
\end{tabular}

